\title{
First possible evidence of parasite infestation in Upper Devonian Discosorida (Nautiloidea)
}

\author{
Aleksandr A. Mironenko' ${ }^{1}$ \\ Received: 14 March 2018 / Accepted: 25 April 2018/Published online: 9 May 2018 \\ (C) Akademie der Naturwissenschaften Schweiz (SCNAT) 2018
}

\begin{abstract}
The small, but rather deep pit in the internal mould of the body chamber of Upper Devonian Cyclopoceras (nom. nov.) abundans (Taxyceratidae, Discosorida) from Central Russia is described in this paper. Similar pits are known to exist on internal moulds of Paleozoic cephalopod shells including nautiloids and Devonian ammonoids, and are interpreted as imprints of blister pearls: nacreous projections on the inner shell surface formed by mollusk for isolation of parasites. The pit studied herein corresponds with asymmetry of the muscle attachment scars and deformation of the last septum: the largest central pair of the muscle scars are shifted from the center of the ventral side, whereas the last septum is curved apically above the pit. These deformations indicate an abnormal growing of the shell at the latest stages of its development, giving a base for assumption that the pit was caused by a parasitic disease. The assumption of an appearance of this abnormality due to an attack by a drilling predator seems less likely. This finding is the first known possible imprint of blister pearls in Discosorida.
\end{abstract}

Keywords Discosorida $\cdot$ Nautiloidea $\cdot$ Devonian $\cdot$ Parasites $\cdot$ Russia $\cdot$ Cyclopoceras

\section{Introduction}

The shells of cephalopod mollusks preserve traces of a wide range of events which occurred throughout their lives, especially the traces of predator attacks and parasitic infestations. Predators generally left sufficiently obvious signs: broken edges of the aperture, mantle damage leading to "scars" on newly formed parts of the shell, and holes in the shell walls (Keupp 2000, 2012; Hoffmann and Keupp 2015 and references therein). It is more difficult to recognize the aftermath of parasitic infestations. The most studied signs of parasites in fossil shells are blister pearls: hemispherical formations located on the inner wall of the shell, which were formed by mollusks to isolate the parasite. They are known in bivalves (Ituarte et al. 2005) and well studied in Paleozoic ammonoids (De Baets et al. 2011, 2015). Inside such pearls in ammonoid conchs, small

Editorial Handling: R. Hofmann.

Aleksandr A. Mironenko

paleometro@gmail.com

1 Geological Institute of RAS, Pyzhevski Lane 7, 119017 Moscow, Russia narrow tubes were found: probably, traces of soft bodies of small worm-like parasites (Keupp 1987; Lehmann 1990; De Baets et al. 2011). On the internal moulds of mollusk shells, the blister pearls are preserved as shallow pits. Isolated findings of blister pearls and their imprints were reported from extant Nautilus (Landman et al. 2001: Fig. 20.1e) and various fossil nautiloids (Kieslinger 1926; Shimansky and Zhuravleva 1961; Manda and Turek 2009; Turek and Manda 2016).

The anomalous asymmetry of the shell shape (symmetropathy) could also be an indication of parasitic activity. The asymmetry which is likely related with parasites is known in ammonoids (De Baets et al. 2015). According to several researchers, the parasites could have been the cause of an abnormal curvature of the phragmocone shell walls and asymmetry of suture lines. Such examples were described among Paleozoic nautiloids (Shimansky and Zhuravleva 1961).

In this paper, the unusual specimen of discosorid nautiloid Cyclopoceras abundans (Zhuravleva, 1972) from Upper Devonian of Central Russia is described. The internal mould of this nautiloid shell bears a deep narrow pit, accompanied by noticeably deformed muscle attachment scars and an abnormally curved last septum. This is 
the first report of a combination of a pit (which is an imprint of protrusion of the inner shell wall) with a curvature of the septum and displacement of the muscle scars in Discosorida. The nature of this anomaly and the possible relation to parasitism are discussed.

\section{Materials and methods}

The specimen MSU EF 13877 was found in an abandoned quarry near the village Krutoye on the left bank of the Truda River in the vicinity of Livny, Orel region, the Central Devonian Field (Fig. 1). It was collected by Elena Kirilishina (Moscow State University) in the upper part of the Upper Devonian (Fransian), clay layers embedded with brown or yellowish-pink limestones (Mironenko and Kirilishina 2012). All cephalopods in this locality are preserved as limestone internal moulds without any traces of aragonite shell layers. Ventral and lateral sides of internal moulds of these nautiloids are more or less well preserved, whereas a dorsal side is almost never preserved in this locality. Together with MSU EF 13877, approximately 20 discosorid moulds were collected without any pits or other visible abnormalities. The specimen is housed at the Earth Science Museum at Moscow State University (MSU), exhibition fund, number MSU EF 13877.

\section{Systematic remarks}

The generic name Cyclopites was proposed by Zhuravleva (1962, p. 110; type species Gomphoceras cyclops Wenjukoff, 1886, by original designation) for a fossil nautiloid genus from the Upper Devonian (Frasnian-Famennian) of
Central and North-Western regions of Russia. However, this name is preoccupied by a generic name of Cambrian aglaspidid arthropod Cyclopites Raasch 1939, which is in active current use in paleontology. Raasch originally proposed the generic name Cyclopina for this arthropod, but this name was already preoccupied and replaced for $C y$ clopites by Størmer (1955). To resolve homonymy, in accordance with article 60 of the International Code of Zoological Nomenclature (1999), Cyclopoceras nom. nov. (type species Gomphoceras cyclops Wenjukoff 1886), is here proposed as a replacement name for Cyclopites Zhuravleva non Størmer (1955).

\section{Results}

Shells of Cyclopoceras are slightly flattened dorso-ventrally, with a pronounced ventral sinus on the aperture (Fig. 2). They are typically $30-50 \mathrm{~mm}$ in width (Zhuravleva 1972), whereas their full length is difficult to measure due to a poor preservation of the phragmocone and aperture. Muscle scars of Cyclopoceras are numerous, typical for the oncoceratomorph type of nautiloid muscle attachment areas (Mutvei 1964). The largest pair of muscle scars is located at the middle of the ventral side (Mironenko and Kirilishina 2012). There is a shallow-wide keel at the middle of the ventral side. Unlike many discosorid genera of Russian platform, described by single fragments, $C y$ clopoceras is very widespread and abundant in Frasnian deposits of Central Russia.

The specimen MSU EF 13877 is a limestone internal mould of the body chamber without a phragmocone and aperture (Fig. 3). It is $33 \mathrm{~mm}$ in length, $38 \mathrm{~mm}$ in width, and the thickness in the dorso-ventral direction is $28 \mathrm{~mm}$.
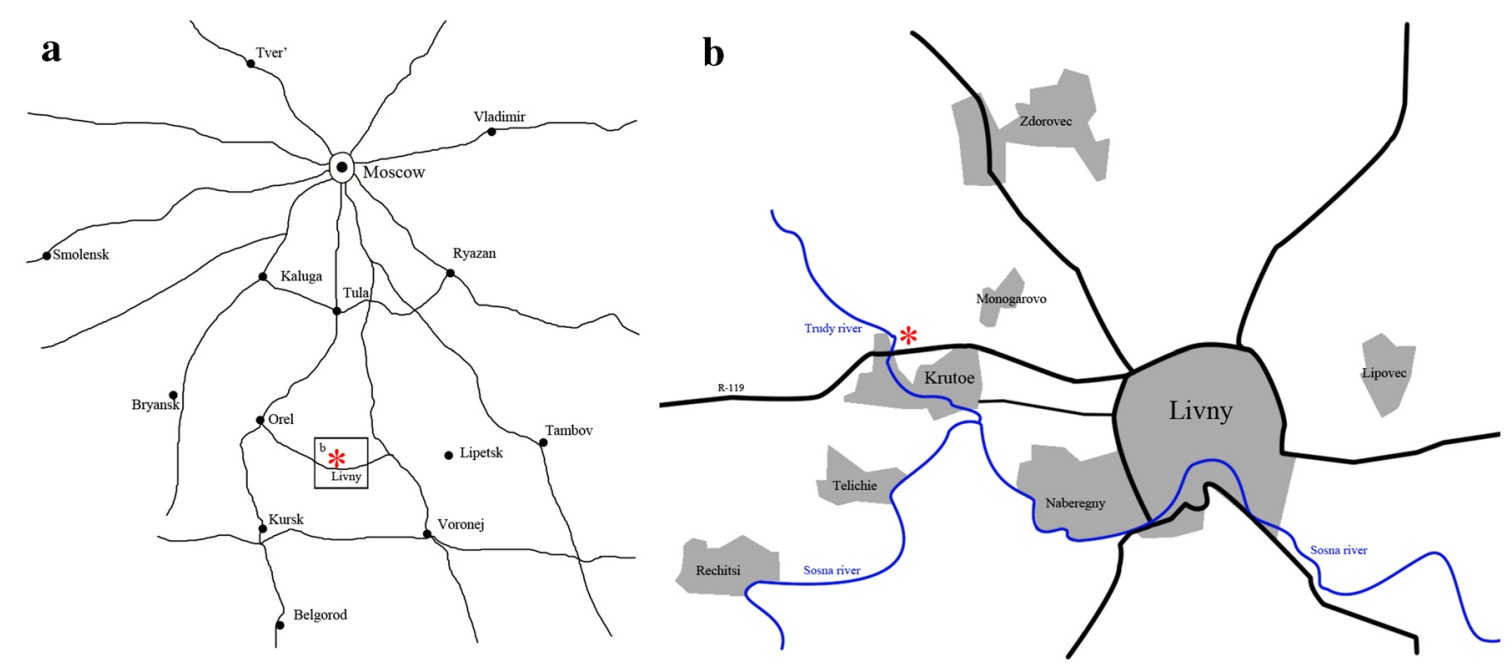

Fig. 1 Maps of the locality. a General view on the Central Russia. b Vicinity of Livny. Locality is marked by asterisks; its coordinates are $52^{\circ} 27^{\prime} 01.4^{\prime \prime} \mathrm{N}, 37^{\circ} 28^{\prime} 17.9^{\prime \prime} \mathrm{E}$ 


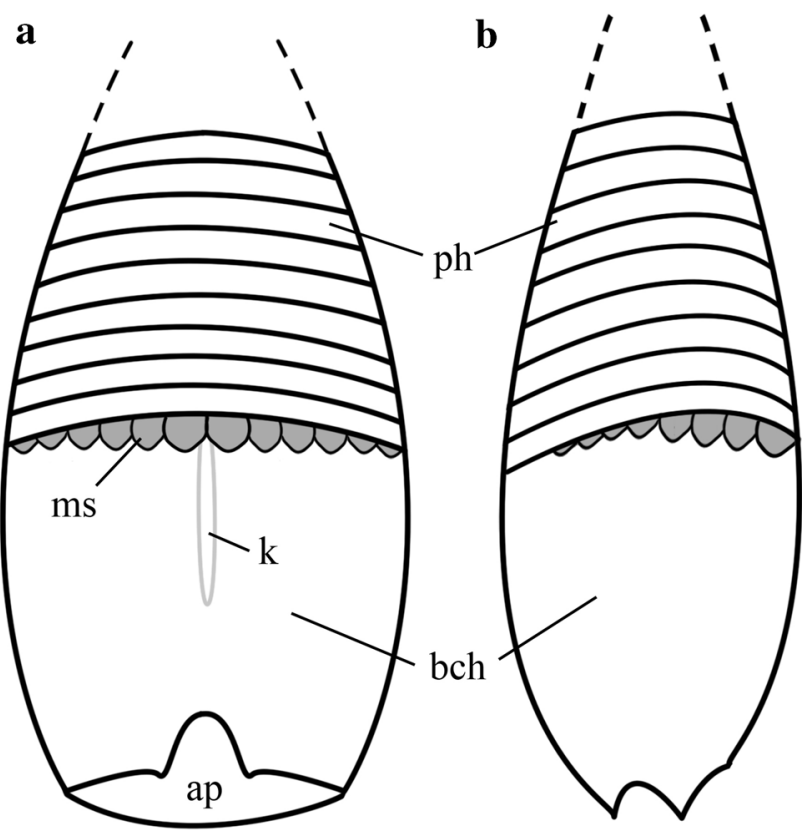

Fig. 2 Scheme of Cyclopoceras abundans shell. a Ventral view. b Lateral view. $p h$ phragmocone, $b c h$ body chamber, $m s$ muscle scars, $k$ shallow ventral keel, ap aperture
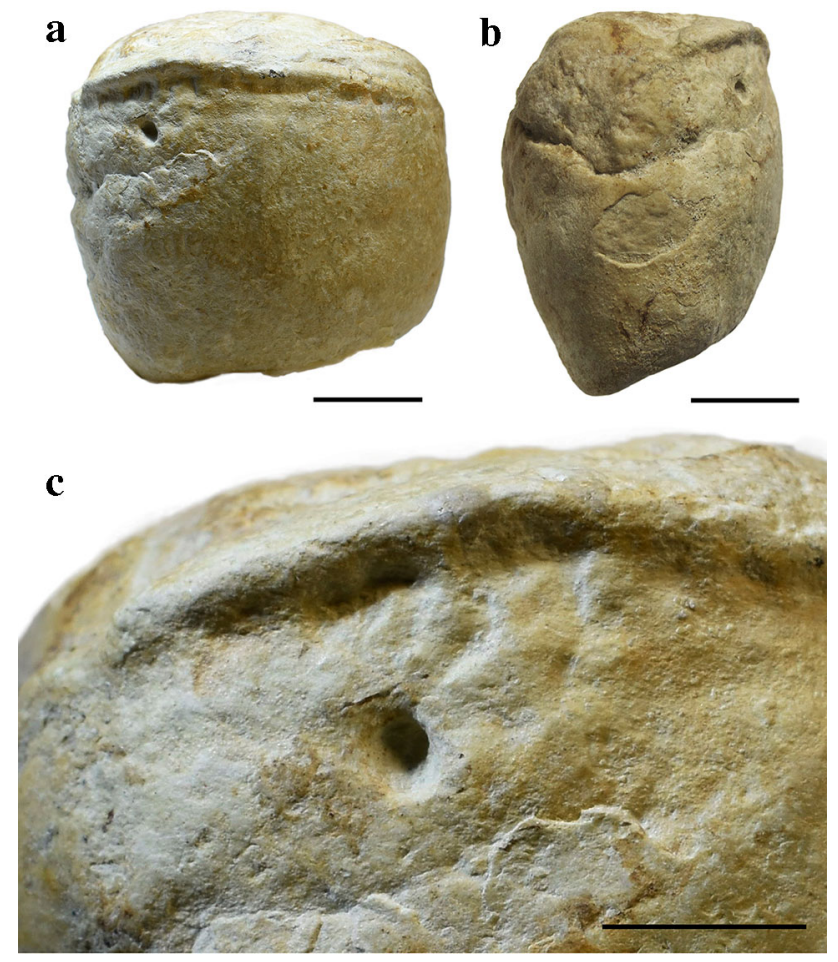

Fig. 3 Cyclopoceras abundans No MSU EF 13877. a Ventral view, b lateral view, and c enlarged view on the pit. Scale bars for a, b $1 \mathrm{~cm}$, and for c $5 \mathrm{~mm}$

The body chamber slightly contracts towards the aperture. A siphuncle opening on the imprint of the last septum and a shallow keel at the center of the ventral side are preserved.
A belt of muscle attachment scars, typical for oncoceratomorph nautiloids (see Mutvei 1964), is located along the last septum. A slightly elongated pit is clearly visible on the right side of the ventral part of the body chamber in front of the attachment scars. The walls of this pit are nearly plumb, but the bottom is concave and the edges are smoothed. The pit is $2-2.5 \mathrm{~mm}$; its deep is approximately $2 \mathrm{~mm}$. The shell layers are not preserved in this specimen, however, judging by the shape of the pit, the slightly elongated bell-shaped projection must have been located on the inner surface of the body chamber wall where the pit appeared in the internal mould.

Cyclopoceras abundans like other discosorids has a belt of small muscle attachment scars consisting of shallow depressions and tubercles around the last septum. $C y$ clopoceras has 10-11 pairs of muscle attachment scars on the ventral side of the shell (Mironenko and Kirilishina 2012). The size of these scars increases to the middle of the ventral side, and therefore, the largest scars are normally located above the mid-ventral shallow keel (Mironenko and Kirilishina 2012). In the specimen studied herein attachment scars are anomalous: a pair of the largest scars is significantly shifted to the right and situated above the pit. Ten scars are located on the right side from the largest pair, but, on left side, there are only six scars. The shape of the last septum is also unusual. Normally, Cyclopoceras abundans septa are lenticular, but, in this specimen, the last septum is asymmetric and curved apically above the pit (Fig. 4). At the same time, the general shape of the body chamber, a position of central keel on the ventral side, and the location of the siphuncle are not distorted. The siphuncle opening is at the middle of the ventral part of the septum imprint in this specimen and the shallow keel is in front of it on the center of the ventral side, as well as in other Cyclopoceras moulds.

\section{Discussion}

Sublethal injuries of shell abnormalities have never been reported from the discosorid shells in Russia. The pits in the shells or internal moulds of these nautiloids also have never been described. The lack of shell layers makes it difficult to determine how exactly the pit appeared; however, the deformation of the muscle attachment scars and last septum with the remaining shape of the body chamber clearly indicate that the pit had appeared when the animal was alive, during the shell formation process. Theoretically, the shape of the last septum could have been distorted by post-mortem processes, but the position of the largest muscle scars could not have changed after the death of the animal. 
Fig. 4 Comparison of two Cyclopoceras abundans specimens from the same locality and layer-normal and with a pit, both in ventral view, with their schematic drawing. a Specimen No MSU EF 13877 , b specimen No MSU EF 13876. Scale bars are $1 \mathrm{~cm}$
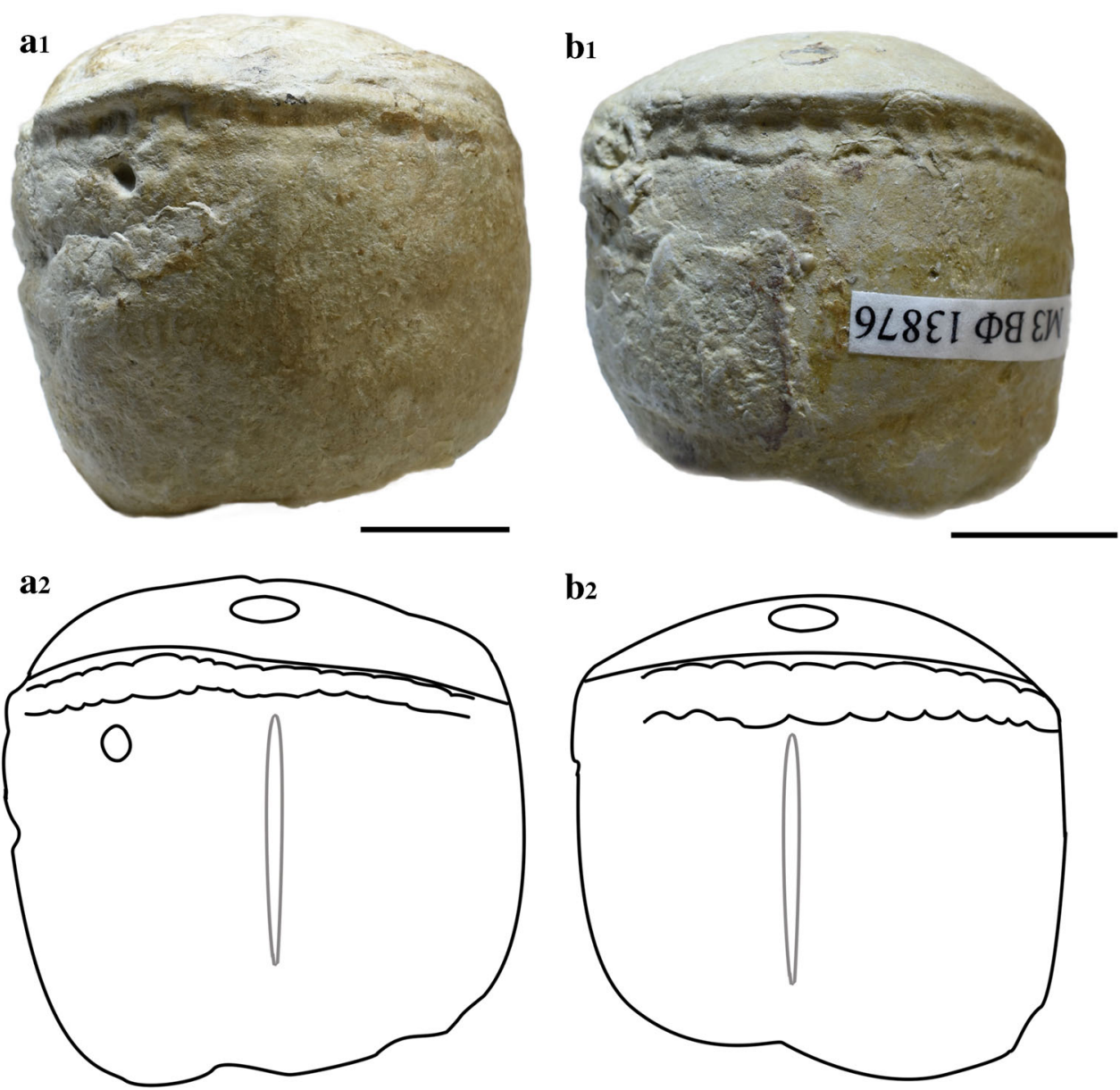

The absence of deformation of the body chamber mould and a normal position of the siphuncle and mid-ventral shallow keel also confirm the appearance of the pit, while the animal was alive. In the case of post-mortem deformation of the shell or of the internal mould, the shape of the body chamber as well as the position of the keel and siphuncle would have changed. In the cases of post-mortem drilling of the shell or the fossilized internal mould by any macroboring organism on the sea bottom or if the pit is an imprint of some epizoan which lived inside an empty shell, the shape of the muscle scars and septum must not have changed, since they must have formed in such cases before a drilling event or settlement of an epizoan. Consequently, the pit is a trace of a protrusion on the inner shell wall which must have appeared when both the animal was alive and the shell development was not fully completed.

The question arises: what was the reason for the formation of such local protrusion and distortion of the shape of a growing septum and muscle scars? It cannot be a bite or shell breakage: the bite traces are more shallow and wider than this pit (see Keupp 2012; Hoffmann and Keupp 2015). Even if a predator had punctured the wall of the body chamber, it is highly unlikely that the hole would have been so small and that the regeneration would have led to such an inner protrusion (see healed punctures on ammonite shells in Keupp 2006).

Nevertheless, the pit is probably a trace of a healed boring of the shell wall produced by some boring predator or, perhaps, the pit is a trace of parasitic activity, similar to blister pearls, described in ammonoids (De Baets et al. 2011, 2015). Due to the preservation as internal mould, both hypotheses seem possible; however, some assumptions can be made based on circumstantial evidence. While the distortion of the last septum may be explained by the protrusion on the inner body chamber surface playing a role as a physical obstacle for the rear part of the mantle, the displacement of the muscle scars is likely related to the damage of the soft tissues. This damage could have appeared during an attack from a drilling predator as well as from the action of a parasite.

The shells of Recent Nautilida (Nautilus and Allonautilus) often bear oval-shaped borings produced by octopods (Saunders et al. 2010). However, such borings (they are belonging to ichnotaxon Oichnus ovalis) have never been found on the shells in pre-Cenozoic strata (Klompmaker et al. 2014; Zonneveld and Gingras 2014). Circular 
drillings, usually interpreted as borings produced by gastropods (Oichnus ispp.), are known starting from the Cambrian (Bicknell and Paterson 2017). In the Devonian strata, such drillings are also very abundant (Baumiller 1993, 1996; Leighton 2003). However, all these borings were found on benthic fauna (brachiopods, bivalves, gastropods, echinoderms, etc.), whereas Cyclopoceras must have been actively swimming animals (their shells have a noticeable hyponomic sinus on the ventral side of the aperture) and it is highly improbable that they could have become the prey of crawling gastropods. The only example of borings, which are probably related with gastropods on the nautiloid shell (Upper Jurassic Paracenoceras), was depicted by Keupp (2012), the nature of these holes is doubtful. Certainly, it cannot be excluded that among Early Paleozoic drilling predators, there were not only gastropods, but also some cephalopods which were able to prey on other cephalopods. However, to date, the drillings have never been found on the shells of Paleozoic ammonoids and nautiloids, and therefore, the drilling hypothesis for the explanation of the pit in Cyclopoceras does not seem plausible.

The small width of the pit with a rather noticeable depth is also a piece of evidence in favor of the parasitic version. Cephalopod mollusks usually repair holes in the body chamber walls forming additional nacreous layers from the inner surface of the chamber (Keupp 2006), i.e., they put a patch on the hole. However, in this case, there was no flat patch on the inner surface of the body chamber, but a prominent hemispherical pearl. Such pearls are the result of mollusk reaction to parasitic infestation rather than to the hole in the shell wall (De Baets et al. 2011, 2015). Blister pearls and their imprints are poorly known in nautiloids. The imprints of hemispherical pearls in Paleozoic nautiloids were described and depicted-to the author's knowledge-only once: in Silurian oncocerid Pomerantsoceras pollux (Manda and Turek 2009). At the same time, hemispherical pearls and their imprints in the internal moulds are widespread among Devonian ammonoids (De Baets et al. 2011, 2015). Occasionally, they can be found in Jurassic ammonites (Keupp 2000, 2012; Mironenko 2012, 2016). However, in ammonoids, they have never been reported in relation to shell abnormalities, such as septa or muscle scar distortion. Pathological distortion of the septa in nautiloids, which was likely related with parasitic activity, had been reported for nautiloids only twice: in Silurian oncocerid nautilod Amphicyrtoceras depressum (Shimansky and Zhuravleva 1961, Fig. 34 d) and Cretaceous nautilid Eutrephoceras sp (Shimansky and Zhuravleva 1961, Fig. 34 b, c). Another example of abnormally curved septa in orthoconic nautiloid was depicted by Klug et al. (2008, pl. 5, Figs. 16, 17). In ammonoids, pathologically distorted septa have been described several times (Keupp and Mitta 2004; Keupp 2012), but, as in the case of nautiloids, these abnormalities are not related with pits.

Not only blister pearls, but also "symmetropathy" (Hengsbach 1991) — pathological asymmetry of a bilaterally symmetrical shell which is not related to any injuriesare considered as evidence of parasitism. Symmetropathies are very well known in ammonoids (see De Baets et al. 2015), but have never been reported from discosorids. Asymmetry of the muscle scars of the Cyclopoceras studied herein can be considered as the first known symmetropathy in Discosorida. It is related to the pit on an internal mould, but not with injury or shell breakage. Certainly, the only unambiguous evidence in favor of the parasitic hypothesis would be a preserved track of the parasite within the pearl (De Baets et al. 2011, 2015), but the shape of the pit in Cyclopoceras abundans as well as muscle scar and septum deformations both support this interpretation.

A considerable effect of the parasite infestation (asymmetry of the muscle attachment scars and distortion of the septa) as well as a rarity of such findings may indicate that the studied Cyclopoceras could have been a false host for the parasite. It is still an open question what animal could have been a main host. It is unlikely that the ammonoids were, since they have never been reported from the locality where the studied specimen was found. However, other invertebrates (not only cephalopods) could have been hosts of the parasite.

\section{Conclusions}

The malformations of shell development in the Upper Devonian Cyclopoceras abundans from Central Russia described herein are likely related with parasitism rather than with damage from a predator attack. The pit in the internal mould of the Cyclopoceras body chamber most likely is an imprint of a blister pearl, whereas a shift of the muscle scars from their normal position together with deformation of the last septum could have been related to mantle damage, produced by a parasite or with mantle displacement due to the presence of a blister pearl. This finding is the first known case of parasitism in Discosorida and a very rare combination of symmetropathy with a blister pearl in cephalopod mollusks.

Acknowledgements I am very grateful to Elena Kirilishina (Moscow State University, Russia) who collected the specimen described herein and drew my attention to it. Special thanks to Steve Ford (Vancouver, Canada) who went over and edited the manuscript with me to improve English. Irina Smurova (Moscow) made photos to this article. I am also very grateful to René Hoffmann (Ruhr-Universität Bochum, Bochum, Germany) and an anonymous reviewer for the important and 
helpful comments which helped to greatly improve the manuscript. The research was supported by the program of the Presidium of Russian Academy of Sciences no 17 (project no 0135-2018-0050).

\section{References}

Baumiller, T. K. (1993). Boreholes in Devonian blastoids and their implications for boring by platyceratids. Lethaia, 26, 41-47.

Baumiller, T. K. (1996). Boreholes in the Middle Devonian blastoid Heteroschisma and their implications for gastropod drilling. Palaeogeography, Palaeoclimatology, Palaeoecology, 123, 343-351.

Bicknell, R. D. C., \& Paterson, J. R. (2017). Reappraising the early evidence of durophagy and drilling predation in the fossil record: implications for escalation and the Cambrian Explosion. Biological Reviews. https://doi.org/10.1111/brv.12365.

De Baets, K., Keupp, H., \& Klug, C. (2015). Parasites of ammonoids. In C. Klug, D. Korn, K. De Baets, I. Kruta, \& R. H. Mapes (Eds.), Ammonoid paleobiology, volume I: from anatomy to ecology. Topics in geobiology (Vol. 43, pp. 837-875). Dordrecht: Springer.

De Baets, K., Klug, C., \& Korn, D. (2011). Devonian pearls and ammonoid-endoparasite co-evolution. Acta Palaeontologica Polonica, 56(1), 159-180.

Hengsbach, R. (1991). Studien zur Paläopathologie der Invertebraten II: die Symmetropathie, ein Beitrag zur Erforschung sogenannter Anomalien. Senckenbergiana Lethaea, 71(3/4), 339-366.

Hoffmann, R. \& Keupp, H. (2015). Ammonoid paleopathology. In Klug, C., Korn, D., De Baets, K. Kruta, I. \& Mapes, R. H. (Eds.), Ammonoid paleobiology, Volume I: from anatomy to ecology. Topics in Geobiology, 43, 877-926, Springer, Dordrecht.

Ituarte, C., Cremonte, F., \& Zelaya, D. G. (2005). Parasite-mediated shell alterations in Recent and Holocene sub-Antarctic bivalves: the parasite as modeler of host reaction. Invertebrate Biology, 124(3), 220-229.

Keupp, H. (1987). Perlen (Schalenkonkretionen) bei Dactylioceraten aus dem fränkischen Lias. Jahresmitt Naturhist Ges Nürnberg, 1986, 97-102.

Keupp, H. (2000). Ammoniten-Paläobiologische Erfolgsspiralen (p. 165). Stuttgart: Jan Thorbecke Verlag.

Keupp, H. (2006). Sublethal punctures in body chambers of Mesozoic ammonites (forma aegra fenestra n.f.), a tool to interpret synecological relationships, particularly predator-prey interactions. Paläontologische Zeitschrift, 80(2), 112-123.

Keupp, H. (2012). Atlas zur Paläopathologie der Cephalopoden. Berliner paläobiologische Abhandlungen, 12, 1-390.

Keupp, H., Mitta, V.V. (2004). Septenbildung bei Quenstedtoceras (Ammonoidea) von Saratov (Russland) unter anomalen Kammerdruckbedingungen. Die Mitteilungen aus dem GeologischPaläontologischen Institut der Universität Hamburg, 88, 51-62.

Kieslinger, A. (1926). Untersuchungen an triadischen Nautiloideen. Paläontologische Zeitschrift, 7(1), 101-122.

Klompmaker, A. A., Portell, R. W., \& Karasawa, H. (2014). First fossil evidence of a drill hole attributed to an octopod in a barnacle. Lethaia, 47(3), 309-312.

Klug, C., Kroger, B., Korn, D., Rucklin, M., Schemm-Gregory, M., De Baets, K., et al. (2008). Ecological change during the early Emsian (Devonian) in the Tafilalt (Morocco), the Origin of the Ammonoidea, and the First African Pyrgocystid Edrioasteroids,
Machaerids and Phyllocarids. Palaeontographica Abtheilung A, 283, 83-176.

Landman, N. H., Mikkelsen, P. M., Bieler, R., \& Bronson, B. (2001). Pearls: a natural history. New York: Abrams.

Lehmann, U. (1990). Ammonoideen, Leben zwischen Skylla und Charybdis (p. 257). Stuttgart: Enke.

Leighton, L. R. (2003). Morphological response of prey to drilling predation in the Middle Devonian. Palaeogeography, Palaeoclimatology, Palaeoecology, 201, 221-234.

Manda, Š., \& Turek, V. (2009). Minute Silurian oncocerid nautiloids with unusual colour patterns. Acta Palaeontologica Polonica, 54(3), 503-512.

Mironenko, A.A. (2012). Traces of lifetime damage on the shells of Upper Jurassic (Upper Volgian) Kachpurites (Craspeditidae, Ammonoidea). In: Leonova, T.B., Barskov, I.S., Mitta, V.V. (Eds.), Contributions to current cephalopod research: morphology, systematics, evolution, ecology and biostratigraphy, proceeding of conference (Moscow, 9-11 April, 2012), pp. 109-111. Borissiak Paleontological Institute RAS, Moscow. [in Russian, with English abstract].

Mironenko, A. A. (2016). A new type of shell malformation caused by epizoans in Late Jurassic ammonites from Central Russia. Acta Palaeontologica Polonica, 61(3), 645-660.

Mironenko, A., \& Kirilishina, E. (2012). Attachment muscle scars in Devonian Discosorida (Nautiloidea) in the exposition of the Earth Science Museum. Life of the Earth: Geology, geodynamics, ecology, and museology. Collection of scientific papers of the Earth Science Museum of Moscow State University, 34, 290-302. [in Russian].

Mutvei, H. (1964). Remarks on the anatomy of recent and fossil Cephalopoda. Stockholm Contributions in Geology, 11, 79-102.

Raasch, G.O. (1939) Cambrian Merostomata. Special Papers of the Geological Society of America, vol 19, (p. 146)

Saunders, W.B., Spinosa, C., Davis, L.E. (2010). Predation on Nautilus. In: B.W. Saunders and N.H. Landman (Eds.), Nautilus: the biology and paleobiology of a living fossil, reprint with additions. Topics in geobiology, vol 6, (pp. 201-215).

Shimansky, V. N., \& Zhuravleva, F. A. (1961). Fundamental questions of the systematics of the nautiloids and related groups. Trudy Paleontologitscheskogo instituta Akademii nauk, 90, 1-175. [in Russian].

Størmer, L. (1955). Merostomata. In Moore, R.C. (Ed.) Treatise on invertebrate paleontology. Part P. Arthropoda 2 (pp. 4-41). Boulder, Colorado \& Lawrence, Kansas: Geological Society of America and University of Kansas Press.

Turek, V., \& Manda, Š. (2016). Early ontogeny, anomalous growth, and healed injuries in the Silurian nautiloid Ophioceras Barrande-Implications for hatching and the autecology of the Tarphycerida. Bulletin of Geosciences, 91(2), 331-366.

Zhuravleva F.A. (1962). Order Oncoceratida. Fundamentals of Paleontology. Cephalopod mollusks I. Moscow, Academy of Sciences, USSR, pp. 101-115 (Osnovy paleontologii. Otryad Oncoceratida. Molluski golovonogie I. Moskva, AN SSSR, pp. 101-115) [in Russian].

Zhuravleva F.A. (1972). Devonian Nautiloids: Order Discosorida Moscow: Nauka, (p. 134) [in Russian].

Zonneveld, J. P., \& Gingras, M. K. (2014). Sedilichnus, Oichnus, Fossichnus, and Tremichnus: 'small round holes in shells' revisited. Journal of Paleontology, 88(5), 895-905. 